\title{
Detection of Alpha-1 antitrypsin and Interleukin-8 in meningitis patients
}

Detección de Alfa 1-antitripsina e Iinterleucina-8 en pacientes con

Meningitis

Autor:

Samir K. Abbas (1)

Mayada N. Iqbal (2)

Nahlah G. Abdul Majeed (3)

\section{ARTÍCULO DE INVESTIGACIÓN CIENTÍFICA Y TECNOLÓGICA}

How to cite this paper:

Abbas S K., Iqbal M N., Abdul Majeed N G., Detection of Alpha-1 Antitrypsin and Interleukin-8 in Meningitis Patients. Innovaciencia. 2019; 7 (1): 1-10.

Reception date:

Received: 11 January 2019

Accepted: 2 May 2019

Published Online: 25 October 2019

DOI:

http:/ /dx.doi.org/10.15649/2346075X.656

Keywords:

Meningitis; IL-8; Alpha1antitrypsin; CSF.

\section{ABSTRACT}

Meningitis is a meninges inflammation and the subarachnoid cerebrum spinal fluid that surrounds the spinal cord and brain. Infantile meningitis is a major cause of morbidity $\&$ mortality in various parts of the world; it is earnest disorder owing to the nearness of the location to the brain and spinal cord. It can be caused by virtually any organism; in general viral infections are more common than bacterial, fungal and parasitic infections respectively. Objective: investigation of the Interleukin-8 (IL-8) and Alaph-1 Antitrypsin in the cerebrum spinal fluid of meningitis patients. Material and Method: A study was done at the Medical city and Al-kadimia hospitals included 47 and 20 beings of Patients and Control groups with an overall age range between 11 days to 6 years old. According to the causative agents of the disease, they were divided into three groups: bacterial, viral and control groups. All subjects were monitored for the IL-8 by Enzyme Linked Immunosorbent Assay (ELISA) and Alaph-1 Anti-trypsin by Single Radial Immunodiffusion assay (SRIA) in the cerebrospinal fluid the data was analyzed via using SPSS (chi-squire test) program (version 22). Results and discussion: The results revealed the presence of an elevation concentration of IL- 8 among meningitis disease patients $(484.0695 \mathrm{pg} / \mathrm{ml})$, high concentration of IL-8 seemed in bacterial meningitis $(825.3250 \mathrm{pg} / \mathrm{ml})$ when compared with its level in viral meningitis $(142.8143 \mathrm{pg} \mathrm{ml})(\mathrm{p}=0.002)$ and control group $(56.3409 \mathrm{pg} /$ $\mathrm{ml})(\mathrm{p}=0.00)$ but no significant difference was found between viral and control groups $(\mathrm{p}=0.679)$. Alpha 1 antitrypsin results appeared high concentration of $(21.6462 \mathrm{mg} / \mathrm{dl})$ and $(16.4000 \mathrm{mg} / \mathrm{dl})$ in bacterial and viral meningitis groups in sequentially, and that concentrations showed differences arrived significantly. The statistical analysis of this research showed a correlation between IL-8 levels and both of neutrophil and lymphocyte in meningitis patients. IL-8 had significant correlation with lymphocyte $(p=0.02)$ in viral group while no significant correlation was appeared between IL-8 and neutrophil. In bacterial group, lymphocytes with IL-8 had weak correlation, in contrary the correlation between neutrophil and IL-8 revealed the significantly correlation $(\mathrm{p}=0.01)$. No correlation was establish concerning the Alpha-1 antitrypsin and the cell's numbers and types. Conclusion: A study indicated that Alpha 1 antitrypsin and IL-8 played an important role in meningitis disease.

\footnotetext{
1) B.Sc. in Biology, High Diploma student in Department of Medical Laboratory Technology, College of Health and Medical Technology, Middle Technical University.

2) Assist. Prof. PhD in Immunology, Department of Medical Laboratory Technology, College of Health and Medical Technology, Middle Technical University, e-mail: dr.mayadanoori@yahoo.com.

(3) Consultant PhD, Immunology laboratory, Teaching laboratories, Baghdad.
} 


\section{INTRODUCCTION}

Meningitis is a severe acute infectious disease started by various microorganisms, including viruses, bacteria, fungi and parasites. Accident rates related to this disease can be as low as $2 \%$ in babies and children, and great of $20-30 \%$ in neonates and adults .Meningitis is an inflammation of the membranes adjacent the brain and spinal cord, including the dura, arachnoid and pia-mater ${ }^{(1)}$.Cytokine is a molecule participated in the modulation of immune and inflammatory methods, Interleukin-8 (IL-8) doings as neutrophils chemoattractant to the inflamed spot ${ }^{(2)}$. Raised Cerebro spinal fluid CSF levels of cytokine are undisputed indicators for meningeal inflammation ${ }^{(3)}$, greatest humoral factors believed playing as share in the vasospasms pathogenesis in subarachnoidal hemorrhage for instance, erythrocyte or platetet derived products-are absent in bacterial meningitis. The hallmark of bacterial meningitis is a massive leucocytes infiltration into the perivascular spaces and the CSF ${ }^{(4)}$. These cells act through synthesis of pro-inflammatory cytokines (IL-1 $\beta$ ), (IL-6), and tumor necrosis factor- $\alpha$ (TNF- $\alpha$ ), which organize the local and systemic features response of host to infection and tissue destruction ${ }^{(5)}$. Enormous amounts of these cytokines had been noticed in CSF patients with bacterial meningitis ${ }^{(6)}$.

Interleukin-8 (IL-8) is produced predominantly by monocytes, but also by fibroblasts and endothelial cells. This chemokine may play a role in various inflammatory and infectious diseases. A variety of cytokine play critical roles in local inflammatory responses in bacterial and aseptic meningitis ${ }^{(7)}$. old investigations showed that level of the following cytokines increase in CSF of aseptic meningitis : IL-1, IL-6, IL-10 ,interferon-gamma (IFN- $\gamma$ ), macrophage inflammatory protein-1 alpha and colony -stimulating factors , but not tumor necrosis factor- $\alpha(\mathrm{TNF}-\alpha)$. Aseptic meningitis is characterized by an initial accumulation of neutrophils in CSF followed by an elevation of monocytes ${ }^{(8,9)}$. An elevation concentration of CSF IL-8 in meningitis has been recorded, with the raise existence more in meningitis with bacteria than aseptic meningitis ${ }^{(10)}$. But the levels in aseptic meningitis patients had inconstant; CSF level of IL-8 was greater than, or comparable to those free meningitis subjects ${ }^{(11)}$. Alpha-1Antitrypsin (A1AT) is a protease inhibitor linkage to the super family of serpin. It is commonly identifed as serum trypsin inhibitor, also denoted as alpha-1 proteinase inhibitor (A1PI) related to its inhibitor effects for an extensive change of proteases ${ }^{(12)}$. It keeps the tissue from enzymes of infammatory cells, chiefy neutrophil elastase ${ }^{(13)}$. Petite is acknowledged about CSF IL-8 kinetics in the course of meningitis. So the study aimed to screen the IL-8 and A1AT levels in CSF patients infected with meningitis to those in control group, and to observe if these markers may be as possible diagnosis tools for distinction bacterial meningitis from viral meningitis.

\section{MATERIALS AND METHOD}

\section{Subjects}

Forty seven patients with meningitis disease admitted to Medical city hospital and Al- Kadimia Hospital between June -October / 2012, their age ranged between (11 days to 6 years). Patients were divided according to the laboratory result of cells and biochemical tests and microbiology analysis into viral meningitis group and bacterial meningitis group infections. A questionnaire table was completed for all patients including personal data (age, sex) and medical history also agreement was taken from each patient (fever, nausea, and headache). Twenty seemingly healthy subjects have been involved as a control group, who matched the patients study group in age and gender. CSF finding of control subjects were normal, these cases were the patients whose clinical finding indicted the need for lumber puncture to reject the diagnosis with meningitis.

\section{Collection of Cerebrospinal fluid}

Collection CSF was done by a skilled medical staff or health employee. It was collected aseptically to prevent organisms being introduced into the central nervous system. The fluid is usually collected from the arachnoid space. A sterile wide bore needle is implanted between the fourth and fifth lumbar vertebrae and the CSF is allowable to drip into sterile container ${ }^{(14)}$. 
Measurement of interleukin-8 and alpha-1 antitrypsin

All samples were quantified for (interleukin- 8 and alpha-1 antitrypsin) in CSF by using ELISA kit manufactured by Cusabio - China and Radia Immuno-diffusion (RIA) kit manufactured by Immuchem.

\section{Statistical investigation}

Appropriate statistical methods were used to evaluate and assess the data. ANOVA test, multiple comparisons by LSD, Person correlation was used to reach a decision. Differences were significant when the two tailed $\mathrm{p}$ value was $<0.05$. All the statistical investigation was prepared by the SPSS version 15 and excels application.

\section{RESULTS}

Table 1 shows the baseline characteristics of the studied samples according to history evaluation, physical and CSF test findings. The control group was distinct by count of inflammatory cells $<5 \mathrm{x}$ $10^{6} \mathrm{cell} / \mathrm{l}$ in CSF and negative for bacteriologic and virologist findings.

Table 1. Prevalence and Clinical features of studied groups.

\begin{tabular}{|c|c|c|c|}
\hline$\underbrace{\text { Study group }}_{\text {Variable }}$ & $\begin{array}{c}\text { Bacterial group } \\
\text { No }=26\end{array}$ & $\begin{array}{l}\text { Viral group } \\
\text { No }=21\end{array}$ & $\begin{array}{c}\text { Control group } \\
\text { No }=20\end{array}$ \\
\hline Age range (months) & $(0.40-72)$ & $(0.50-72)$ & $(6-120)$ \\
\hline Mean $\pm \mathrm{SD}$ & $21.25 \pm 11.5$ & $15,34 \pm 4.5$ & $45.02 \pm 30.0$ \\
\hline \multicolumn{4}{|l|}{ Gender NO (\%) } \\
\hline - Female & $8(30.8 \%)$ & $12(57.1 \%)$ & $7(35 \%)$ \\
\hline - Male & $18(69.2 \%)$ & $9(42.9 \%)$ & $13(65 \%)$ \\
\hline \multicolumn{4}{|l|}{ Clinical finding $*$} \\
\hline - Fever & $93.1 \%$ & $74 \%$ & $56 \%$ \\
\hline - Nausea or vomiting & $67 \%$ & $69 \%$ & $71 \%$ \\
\hline - Headache & $20 \%$ & $33 \%$ & $36 \%$ \\
\hline CSF Neutrophil count $\left(\right.$ cells $\left./ \mathrm{mm}^{3}\right)$ & $438.2308^{*}$ & 6.0000 & 1 \\
\hline CSF Lymphocyte count $\left(\right.$ cells $\left./ \mathrm{mm}^{3}\right)$ & $1538.6250^{*}$ & 55.8571 & 1.3333 \\
\hline CSF Protein (mg / l) & $170.8846^{*}$ & 40.2857 & 24.5455 \\
\hline CSF Glucose ( mg/dL) & 42.6923 & 39.1429 & 46.5000 \\
\hline
\end{tabular}

*Percentages do not add to $100 \%$ then several of clinical manifestations can be establish

* Significant differences at $\mathrm{P}<0,05$ level

Cerebrospinal fluid levels of IL-8 and alpha -1 antitrypsin in studied groupsIL-8 level of CSF was assessed in three study groups, as presented in table (2), the mean IL-8 concentration of CSF in bacterial meningitis's patients $(825,3250 \mathrm{pg} / \mathrm{ml})$ was significantly higher than both viral meningitis $(142,8143 \mathrm{pg} / \mathrm{ml})$ and control group $(56,3409 \mathrm{pg} / \mathrm{ml})$ while CSF IL-8 of viral meningitis group was higher than that for control group but with no significant differences. The A1AT was screening in the study groups. No distinctive difference was found in mean of A1AT in CSF, but little tangible deference between the bacterial group separately from the viral and control group, as in table 2. 
Table 2. Cerebrospinal fluid levels of IL-8and A1AT in studied group

\begin{tabular}{|c|c|c|c|c|}
\hline Variable & $\begin{array}{c}\text { Bacterial group } \\
\quad \mathrm{No}=26\end{array}$ & $\begin{array}{l}\text { Viral group } \\
\text { No }=21\end{array}$ & $\begin{array}{c}\text { Control group } \\
\text { No }=20\end{array}$ & p- value \\
\hline Il-8 Range (pg /ml) & $(1.38-2566.80)$ & $(20-554.10)$ & $(22-130.841)$ & $\begin{array}{l}\text { Bacterial } * \text { viral }=0.002 \mathrm{~S}^{*} \\
\text { Bacterial } * \text { Normal }=0.00 \text { H.S }\end{array}$ \\
\hline Mean \pm SD & $825.3250 \pm 67.44$ & $142.8143 \pm 18.83$ & $56.3409 \pm 13.045$ & Viral $*$ Normal $=0.679$ N.S $* *$ \\
\hline $\begin{array}{l}\text { A1AT varies No. } \\
(\% \text { of }+ \text { ve test })\end{array}$ & $13(50 \%)$ & $6(25 \%)$ & $15(75 \%)$ & 0.693 N.S* \\
\hline Mean $(\mathrm{mg} d \mathrm{dl}) \pm \mathrm{SD}$ & $21.6462 \pm 9.6$ & $16.4000 \pm 4.5$ & $0.6 \pm 0.11$ & \\
\hline
\end{tabular}

$* \mathrm{~S}=$ Significant differences at $\mathrm{p}<0.05$ level.

$* *$ H.S $=$ High significant differences at $\mathrm{p}<0.01$ level

$* * *$ N.S $=$ Non significant differences at $\mathrm{p}>0.05$ level.

\section{Correlation between IL-8 and lymphocytes and neutrophils among}

Figure 1 showed an important correlation amid CSF IL-8 in bacterial meningitis patients and neutrophils counts $(\mathrm{R} 2=0.179 ; \mathrm{p}<0,05)$. CSF IL-8 concentration of viral meningitis and neutrophilic counts results no correlation was appeared. IL-8 levels in bacterial meningitis group associated with lymphocytes count and non-significant positive correlation $(\mathrm{R} 2=0.424, \mathrm{p}>0.05)$ figure $(2)$, IL-8 in viral meningitis patients exhibited the same trend as in bacterial meningitis and had linear correlation between IL-8 and lymphocytes which reach significantly positive correlation $\left(\mathrm{R}^{2}=0.007, \mathrm{p}<0.05\right)$ (figure 3).

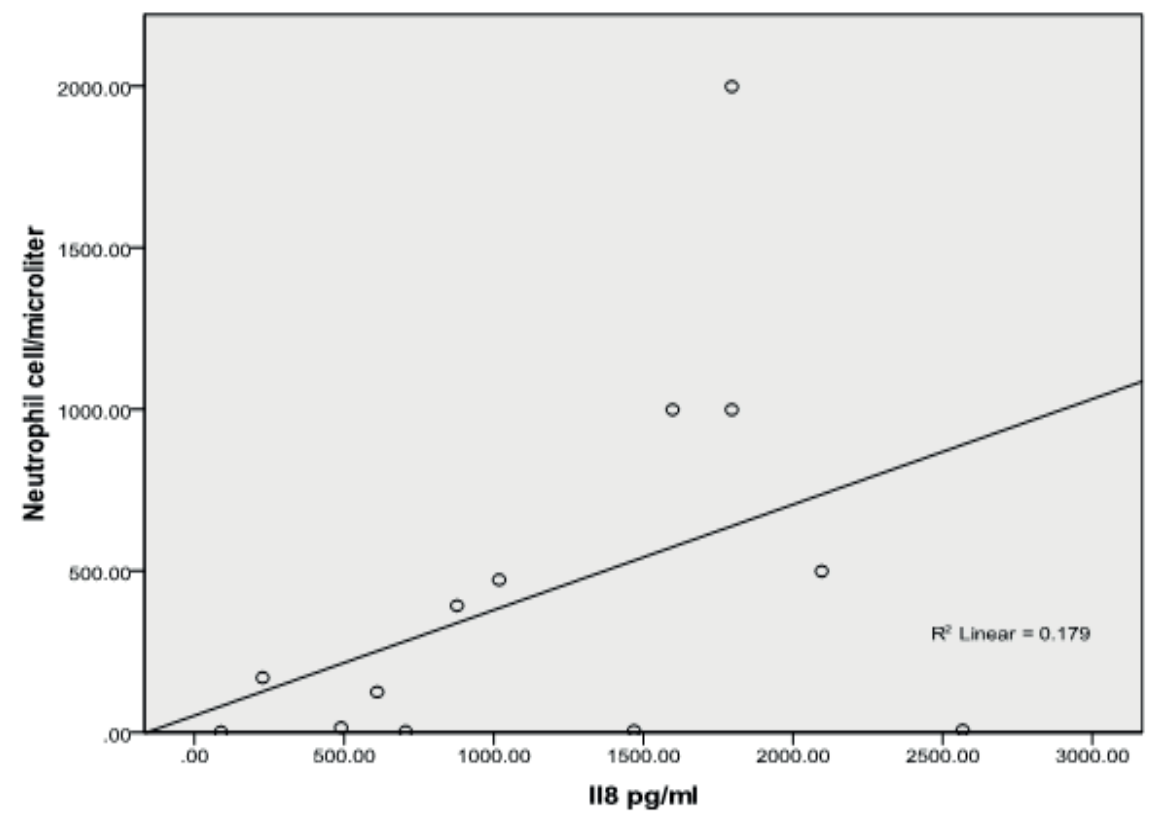

Figure 1. The correlation between the IL-8 and neutrophil cell count in bacterial meningitis. 


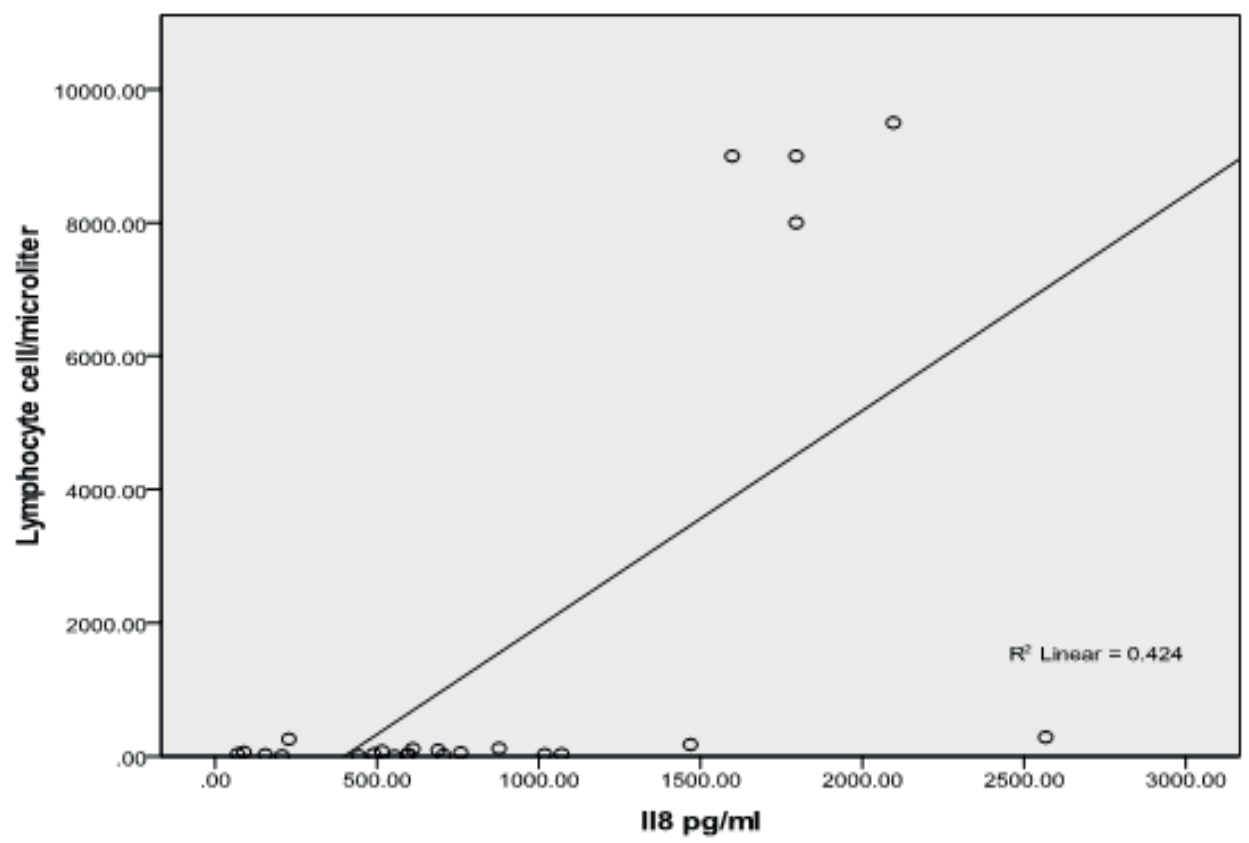

Figure 2. The correlation between the lymphocyte cells and the IL-8 in bacterial meningitis.

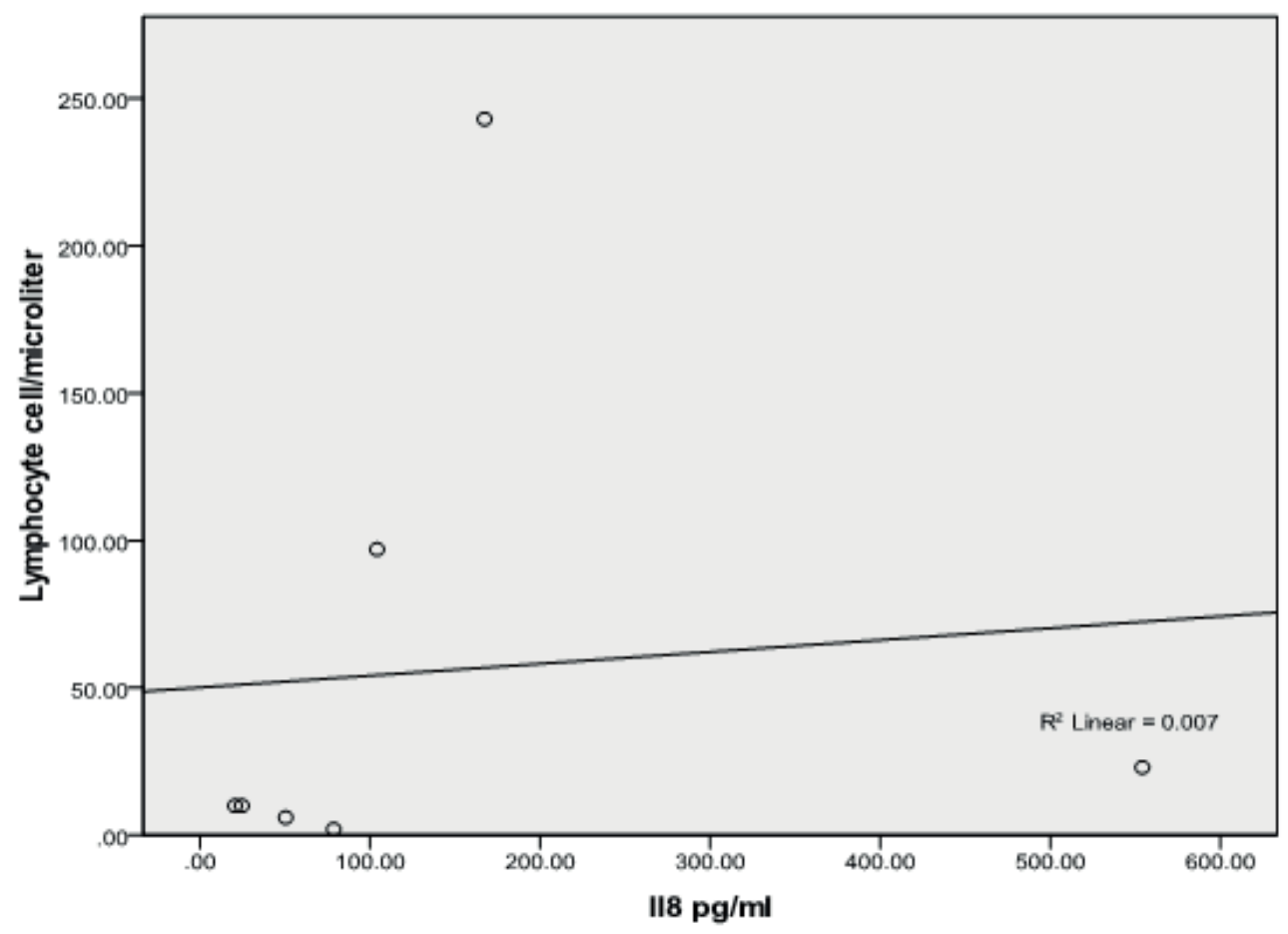

Figure 3. The correlation between the lymphocyte and IL-8 in viral meningitis.

\section{DISCUSSION}

The study exhibited high IL-8 concentrations in both bacterial and viral meningitis groups indicating that this particle may acts as a mediator in meningial inflammation, the results were agree with other research which used level of IL-8 to compare between cases of bacterial and viral meningitis, also other studies revealed that in control CSF (without inflammatory central nerves system disease), little 
if any IL-8 was detectable, but during both bacterial $(15,16,17)$ and viral meningitis ${ }^{(18)}$, significant up regulation of IL-8 has been demonstrated. Studies done by Lopez-Cortez and Ostegard et al. ${ }^{(19)}$ showed that patients infected by bacterial meningitis with higher concentrations of in IL-8 of CSF matched to aseptic meningitis cases. The researchers proposed a cut off at $2500 \mathrm{pg} / \mathrm{dL}$ for CSF IL-8 concentration using the dispersal diagram for concentration.

Bacteria or lipopolysaccharides stimulation the vascular endothelial and monocytes cells to produce IL8 , and is released into blood or tissue fluids ${ }^{(20)}$. Not individualy TNF, IL- 6 and IL-1 but IL- 8 also activate neutrophils in inflammatory sites ${ }^{(21)}$. IL- 8 increases the expression of the integrins on neutrophils. IL-8 appears to be closely related to the switching of adhesion molecule expression from the early selectin adhesion to the integrin-mediated adherence of neutrophils to vascular endothelium. ${ }^{(22)}$ However, how closely IL-8 is related to bacterial meningitis and socalled aseptic meningitis due to viral infections in humans remains to be clarified.

Neutrophils travel into CSF by linkage by endothelial cells and via diapedesis, at that point relief vasoactive lipid autacoids (platelets activating factor, prostaglandins and leukotrienes) and reactive oxygen species. So, the blood brain barrier becomes impaired, causing brain edema and inflammation expansion ${ }^{(23)}$. Cytokines seem to also play a defending character or initiate a stable over-reaction of the immune system finally leading to cell death ${ }^{(24)}$. Together IL-1 $\beta$ and TNF- $\alpha$ are secrete during meningeal inflammation ${ }^{(25)}$ and have been involved in cellular damage ${ }^{(26)}$ .Additionally, it found to start inflammatory steps ${ }^{(27)}$ that comprise the IL- 8 releasing ${ }^{(28)}$. This stimulation can be display by augmented respiratory burst action, the bioactive lipids production, and the release of lysosomal enzymes, possibly causative to injury of tissue ${ }^{(29)}$. IL-8 organize adhesion of neutrophil to endothelial cells ${ }^{(30)}$, possible facilitating the huge inflow of these cells into the subarachnoid space which apparent in bacterial meningitis patients ${ }^{(31)}$. IL-8 synthesis by human microglia increases extra provision to the hypothesis that implication of IL-8 in acute bacterial meningitis pathogenesis and other CNS diseases inclusive of Alzheimer's dis- ease ${ }^{(32)}$.Remarkably, IL-8 and other pro-inflammatory cytokines release happens in meningitis before the neutrophil arrival, propose that induces cells for example microglia and endothelial cells to create IL-8, suggesting that initial contact with bacterial products persuades cells such as microglia and endothelial cells to synthesize IL- $8^{(33)}$. It is necessary to reminder that cut-off value for IL-8 possibly differs dependent to differences of the procedure or reagents used, and essential fix the specific cut-off value under the conditions available to confirm the top accuracy CSF IL-8 concentrations above 1685 $\mathrm{pg} / \mathrm{dL}$ would indicate bacterial meningitis confirming other clinical and laboratory findings, IL-8 measurement is not replacing for CSF protein, glucose or leukocyte examinations, nonetheless relatively added and useful give information which could assistance diagnosis for cases where a perfect diagnosis cannot be got by standard methods. Difference analysis between bacterial and aseptic meningitis in some cases can be problematic. A dependable laboratory sign might simplify the clinical conclusion of interrupting anti-microbial treatment and evading needless hospitalization ${ }^{(19)}$. Results of this study showed no relationship between the A1AT and both IL- 8 and cells in meningitis patients. The archetype of the serpin family is $\alpha 1$ antitrypsin, the inhibitor present at highest concentration in human plasma. Although named $\alpha 1$ antitrypsin, its physiologic target is leukocyte elastase rather than trypsin and for this reason, it is alternatively called $\alpha$-proteinase inhibitor; in this study, the historical name will be retained and sometimes abbreviated to antitrypsin (34). Alpha-1 Antitrypsin (A1AT) play a major role in laboratory investigations to differentiating bacterial and viral meningitis along with CSF cells count ${ }^{(35)}$, we noticed that level of A1AT in the bacterial meningitis $(21.6462 \mathrm{mg} / \mathrm{dl}$ ) was higher than the level of viral meningitis $(16.4000 \mathrm{mg} / \mathrm{dl}$ ) and that agree with Pearl GS et al. ${ }^{\left({ }^{6}\right)}$ but in little variance with no significant correlation is detected.

Human leukocytes have possibly injurious elements inside cytoplasmic granules, excluding proteases accomplished of humiliating connective tissue structures and basement membrane. These proteases comprise elastase, human poly-morphonuclear leu- 
kocyte (PMN) and collagenase. It appeared that increasing poly-morphonuclear cell at inflammation spots, including sites of immune complex deposition, may cause in leakage of these enzymes to the external the cell with following harm to close the structures of tissue. An organization of anti-proteases existing in the tissue plus circulation fluid which functions to inactivate proteases released from inflammatory cells. Alpha- 1 proteinase inhibitor $(\alpha-\mathrm{Pi})$ is an important component of this anti-protease system and is capable of inhibiting both PMN elastase and collagenase. It is believed that the local balance between released protease and tissue anti-protease plays a key role in determining whether damage will occur to connective tissues as a result of inflammation ${ }^{(37)}$.

Circulating neutrophils likely release little, if any, of the stored NE. After ingesting particulates, the neutrophil disgorges the enzyme into phagosomes simultaneously, however, as well as following perturbation of the plasma membrane via specific receptors or surface interaction with tissue components, NE is released into the local environment ${ }^{(38,39)}$.Although extracellular NE may be beneficial in infectious loci or in wounds. It is so potent that its presence in the extracellular milieu is highly dangerous and can lead to marked damage of normal tissue architecture ${ }^{(40)}$, and the greatest abundant in the circulation. Sera levels of A1AT in healthy individual were $350 \mathrm{mg} /$ $\mathrm{dl}$ and can rise fourfold in the course of inflammation representing that $\mathrm{A} 1 \mathrm{AT}$ is an acute phase protein and in cerebrospinal fluid are $0.8 \mathrm{mg} / \mathrm{dl}{ }^{(41)}$. The chief role of A1AT is supposed to be suppression of neutrophil elastase and other endogenous serine proteases $^{(42)}$.

The physiological function of A1AT is the keeping the protease/anti-protease stability. The main activity location of A1AT is in the lower respiratory tract, where it avoids destruction by proteolytic with inhibiting neutrophil elastase. Communication of A1AT with a bacterial virulence factor not described to date would be investigated in more details in future researches. One would suppose that A1AT as a serpin should specially bind to serine proteases. Knappstein S. et al. ${ }^{(43)}$ showed that a typical Enteropathogenic Escherichia coli (EPEC) raise in the existence of A1AT without any growth damage or other clear defect.

Different studies appeared that A1AT able to interfering with the viral entry of human immunodeficiency virus type 1 (HIV-1) to the cell, seemingly by obstructive entry of viral into cell, the process that is intermediated by the viral gp120 and gp41 cover glycoprotein, it has been speculated that A1AT disrupts the interface of gp120 with cell surface proteases complicated in the steps of fusion ${ }^{(44)}$ The data revealed high concentration of CSF IL-8 in bacterial meningitis which corresponded with count of neutrophils agree previous researches of lopez et al., (45) and Ishiguro et al., (46). The data suggest a likely role of IL-8 as PMN leukocytes chemotactic factor in different infectious of the subarachnoid space, not only in pyogenic meningitis. While the findings of our study disagree with ${ }^{(46)}$ who reported that the correlations were significant amid IL-8 levels and counts of mononuclear cells in viral meningitis while non-significantly with bacterial meningitis. The results of Ishiguro and his staff (46) showed the high CSF levels of IL-8 in children with meningitis. IL-8 cause chemo- taxis of neutrophils, also, stimulate neutrophils to secrete intracellular enzymes and controls cell adhesion molecules, potentially helping leucocytes trafficking across the $\mathrm{BBB}{ }^{(47)}$ when neutrophils have traversed the $\mathrm{BBB}$, it caused neutrophils degranulation to liberate chemo-attractants for T-lymphocytes ${ }^{(48)}$ and superoxide production (49) Therefore accesses the activated of neutrophils possibly possess a harmful effects and arranging the IL-8 chemotactic activity could be required to decrease the unhelpful neutrophil influx effects. The interactions among IL-8, neutrophils monocyte, and macrophages, seem to be vital to understand the pathogenesis of inflammation in meningitis ${ }^{(50)}$. Meningitis appeared have to strong correlation with the IL-8 concentration in cerebrospinal fluid.

Conclusion: IL-8 and A1AT in bacterial meningitis was higher than viral meningitis and healthy control groups. The disease seemed strong correlation with the IL-8 level in CSF. 


\section{REFERENCES}

1. Braunwald E, Longo DL, Jameson JL, Infectious diseases In: Braunwald E, (editor). Harrison's Principles of Internal Medicine. $15^{\text {th }}$ ed, New York, Mc Graw-Hill; 2001.

2. Abbas AK, Lichtman AH, Pillai S. Cellular and molecular immunology. 6 ed. Philadelphia: Saunders Elsevier; 2007.

3. Nagafuchi M, Nagafuchi Y, Sato R et al. Adult meningism and viral meningitis, 1997-2004: clinical data and cerebrospinal fluid cytokines. Intern Med 2006; 45(21):1209-12.

4. Joo-Yeon E, Matthijs C. B, Eleonora A., and Diederik van de B. Pneumococcal meningitis: Clinical-pathological correlations (meningene-path) Acta Neuropathol Commun. 2016; 4: 26.

5. Fassbender K, Parrger H, Muller W and Zimmerli W, Interleukin-6 and acute phase protein concentrations in surgical intensive care unit patients: diagnostic signs in nosocomial infection. Crit Care Med, 1993; 21: 1175- 1180.

6. Waage A, Halstensen A, Shalaby R, Brandtzaeg $\mathrm{P}$, Kierulf P and Espevik T, Local production of tumor necrosis factor alpha, interleukin 1, and interleukin 6 in meningococcal meningitis. Relation to the inflammatory response, Exp Med, 1989; 170: 1859-1867.

7. Fukushima K, Ishiguro A and Shimbo T, Transient elevation of granulocyte colony - stimulating factor levels in the cerebrospinal fluid at the initial stage of aseptic meningitis in children , Pediatr Res , 1995; 37: 160-164 .

8. Inaba $\mathrm{Y}$, Ishiguro $\mathrm{A}$ and Shimbo T, The production of macrophage inflammatory protein -1 alpha in the cerebrospinal fluid at the initial stage of meningitis of children, pediatr Res, 1997.

9. Ishiguro A, Suzuki Y, Inaba Y, Komiyama A, et al. , Production of interleukin 10 in the cerebrospinal fluid in aseptic meningitis of children, Pediatr Res, 1996; 40: 610-614.

10. Ostergaard C, Yieng-kow RV , Benfield T, Frimodt-Moller N , Espersen F and Lundgren JD, Inhibition of leukocyte entry into the brain by the selection blocker fucoidin decreases interleukin-1 (IL-1) levels butincreases IL-8 levels in cerebrospinal fluid during experimental pneumococcal meningitis in rabbits, Infect Immun, 2000; 68(6): 3153-3157.

11. Lopez-Cortes LF, Cruz-Ruiz M and Gomez-Mateos J, Interleukin- 8 in cerebrospinal fluid from patients with meningitis of different etiologies : its possible role as neutrophil chemotactic factor, J Infect Dis, 1995; 172: 581-584.

12. Gettins PG., Serpin structure, mechanism, and function, Chem Rev, 2002; 102(12): 804 - 4751.

13. Kushner I, Mackewicz I and Baumann H, Acute phace proteins, Molecular biology, biochemistry and clinical applications, Boca Raton, CRC press , 1993.

14. Cheesbrough M. , District Laboratory Practice in TropicalCountries Part 2, Second Edition, Cambridge University Press, United States of America 2006; pp:442.

15. Halstensen A, Ceska M , Brandtzaeg P, Redl H, Naess A, and Waage A, Interleukin- 8 in serum and cerebrospinal fluid from patients with meningococcal disease, J. Infect. Dis, 1993; 167: 471475.

16. Shapiro S, Miller A, Lahat N, Sobel E, and Lerner A, Expression of matrix metalloproteinases, sICAM-1 and IL-8 in CSF from children with meningitis, J. Neurol. Sci, 2003; 206: 43-48.

17. Abdelmoez AT, Zaky DZ, Maher AM. Role of cerebrospinal fluid IL-8 as a marker for differentiation between acute bacterial and aseptic meningitis. Egypt Soc Parasitol. 2014; 44(1):205-10.

18.Lahrtz, F, Piali L, Nadal D, Pfister HW, Spanaus KS, Baggiolini M, and Fontana A, Chemotactic activity on mononuclear cells in the cerebrospinal fluid of patients with viral meningitis is mediated by interferon-gamma inducible protein-10 and monocyte chemotactic protein-1. Eur. J. Immunol, 1997; 27: 2484-2489.

19. Yoshimura T, Matsushima K, Oppenheim JJ and Leonarde J, Neutrophil chemotactic factor produced by lipopolysaccharide (LPS)-stimulated human blood mononuclear leukocytes: partial characterization and separation from interleukin 1 (IL 1). J. Immunol, 1987; 139: 788-793.

20.Pinto Junior VLL, Rebelo MC, Gomes RN, Assis EF and Boia MN, IL-6 and IL-8 in cerebrospinal fluid from patients with aseptic meningitis and bacterial meningitis: their potential role as 
a marker for differential diagnosis, Braz J Infect Dis, 2011; 15(2): 156- 158.

21. Peveri P, Walz A, Dewald B and Baggiolini M, A novel neutrophil-activating factor produced by human mononuclear phagocytes. J. exp. Med, 1988; 167: 1547-1559.

22.Huber AR, Kukeel SL, Todd RF and Weiss ST, Regulation of transendothelial neutrophil migration by endogenous interleukin 8 . Science, 1991; 254: 99-102.

23. Tureen JH, Dworkin RJ, Kennedy S C, Sachdeva M. and Saande MA, Loss of cerebrovascular autoregulation in experimental meningitis in rabbits. J. clin. Invest, 1990; 85: 577-581.

24.Sa ez-Llorens X, and McCracken Jr, Contribution of cytokines to meningeal inflammation in bacterial meningitis. In In Defense of the Brain: New Concepts in Pathogenesis, Treatment and Prevention of CNS Infections. J. S. Remington and P. K. Peterson, eds. Blackwell Science, Boston, 1997; pp: 107.

25. Glimaker M, Kragsbjerg P, Forsgren M and Olcen $\mathrm{P}$, Tumor necrosis factor-a (TNF- $\alpha$ ) in cerebrospinal fluid from patients with meningitis of different etiologies: high levels of TNF- $\alpha$ indicate bacterial meningitis. J. Infect. Dis, 1993; 167(4): 882-889.

26. Chao CC, Hu S, and Peterson PK, Glia: the not so innocent bystanders. J. Neurovirol, 1996; 2(4): 234-249.

27.Ramilo, O, Sa ez-Llorens X, Mertsola JH, Jafarai KD .Olsen EJ, Yoshinaga HM, Ohkawara S, Nariuchi $\mathrm{H}$, and $\mathrm{McCracken} \mathrm{GH}$, Jr. Tumor necrosis factor and interleukin-1 initiate meningeal inflammation. J. Exp. Med, 1990; 172: 497-507.

28. Matsushima K, Baldwin ET, and Mukaida N, Interleukin-8: novel leukocyte recruitment and activating cytokine. Chem. Immunol, 1992; 51: 236265.

29. Harada A, Mukaida N, and Matsushima K, Interleukin- 8 as a novel target for intervention therapy in acute inflammatory diseases. Mol. Med. Today, 1996; 2: 482-489.

30. Huber AR, Kunkel SL, Todd RF 3rd, Weiss SJ, Regulation of transendothelial neutrophil migration by endogenous interleukin-8, Science, 1991; 254 (5028): 99-102.
31. Tunkel AR and Scheld WM, Pathogenesis and pathophysiology of bacterial meningitis, (1993); Annu. Rev. Med. Vol.6, No.2: 118-136.

32. Meda L, Bonaiuto C, Szendrei GI, Ceska M, Rossi F, and Cassatella MA, b-Amyloid induces the production of interleukin-8 from human monocytes. J. Neuroimmunol, 1995; 59: 25-35.

33. Van Furth AM, Roord J J, and Van Furth R, Roles of proinflammatory and anti-inflammatory cytokines in pathophysiology of bacterial meningitis and effect of adjunctive therapy. Infect. Immun, 1996; 64: 4883-4890.

34.Carrell WR. , alpha-1Antitrypsin: Molecular Pathology, Leukocytes, and Tissue Damage, J. Clin. Invest., 1986; 78: 1427-1431.

35.Jadali F, Sharifi MM, Jarollahi A and Nahidi S, C-reactive protein and lactate dehydrogenase in serum and cerebrospinal fluid in rapid and early diagnosis of child meningitis, Iran J Child Neurology, 2007: 37-46.

36.Pearl GS and Mullins RE, Alpha 1-antitrypsin in cerebrospinal fluid of patients with neurologic diseases , Arch Neurol., 1985; 42(8) :775-777.

37. Carp H. and Janoff A., In Vitro Suppression of Serum Elastase-Inhibitory Capacity by Reactive Oxygen Species Generated by Phagocytosing Polymorphonuclear Leukocytes, J. Clin. Invest. , 1979; 63: 793-797.

38. Weiss S J, Tissue destruction by neutrophils, N Engl J Med, 1989; 320: 365-376.

39.Sandborg RR and Smolen J E, Biology of disease. Early biochemical events in leukocyte activation, Lab Invest, 1988; 59: 300-320.

40.Janoff A, Elastases and emphysema: Current assessment of the protease-antiprotease hypothesism Am Rev Respir Dis, 1985; 132: 417-433.

41. Irani DN, The cerebrospinal fluid in clinical practice, Saundars Elsevier, united states of America, 2009.

42.Pott G B , Chan E D, Dinarello C A, Leland Shapiro, et.al. Alpha1-Antitrypsin is an endogenous inhibitor of proinflammatory cytokine production in whole blood, Journal of Leukocyte Biology, 2009; 85: 886-895.

43. Knappstein S, Ide T, Schmidt MA, and Heusipp G, Alpha -1 Antitrypsin Binds to and Interferes with Functionality of EspB from Atypical and 
Typical Enteropathogenic Escherichia coli Strains , Infect. Immun., 2004; 72: 4344-4350.

44.Shapiro L, Pott G B , and Ralston A H. Alpha-1-antitrypsin inhibits human immunodeficiency virus type 1 , The FASEB Journal, 2001; 15: 115-122 .

45.Lopez-Cortés L F, Cruz-Ruiz M, Gómez-Mateos J, Viciana-Fernandez P, Martinez-Marcos F J, and Pachón J. Interleukin-8 in cerebrospinal fluid from patients with meningitis of different etiologies: its possible role as neutrophil chemotactic factor.J Infect Dis, 1995; 172 (2):581-584.

46.Ishiguro A, Suzuki Y, Inaba Y, Shimbo T. et al. , The production of IL-8 in cerebrospinal fluid in aseptic meningitis of children. Clin Exp Immunol, 1997; 109: 426-430.

47. Adam DH Lloyd AR, Chemokines: leukocyte recruitment and activation cytokines. Lancet, 1997; 349: 490-495.
48. Taub D D, Anver M, Oppenheim J J, Longo D L, and Murphy W J. T lymphocyte recruitment by interleukin-8 (IL-8): IL-8 induced degranulation of neutrophils release potent chemoattractants for human $\mathrm{T}$ lymphocytes both in vitro and in vivo. J Clin Invest, 1996; 97: 1931-1941.

49. Metzner B, Barbisch M, Parlow F, Norgauer J, et al. Interleukin -8 and GRO aloha prime human neutrophils for superoxide anion production and induced up-regulation of $\mathrm{N}$-formyl peptide receptors. J Invest Dermatol, 1995; 104: 789 -791.

50.Singh A, Kulshreshtha R, Mather A. Secretion of the chemokine interleukin- 8 during Japanese encephalitis virus infection. J. Med.Microbiol, 2000; 49: 607-612. 